\title{
Local and geographic variation in grazing intensity by herbivorous crabs in SW Atlantic salt marshes
}

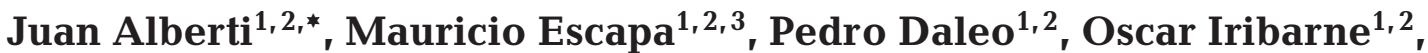 \\ Brian R. Silliman ${ }^{4}$, Mark Bertness ${ }^{5}$ \\ ${ }^{1}$ Departamento de Biología (FCEyN), Universidad Nacional de Mar del Plata, CC 573 Correo Central, B7600WAG, \\ Mar del Plata, Argentina \\ ${ }^{2}$ Consejo Nacional de Investigaciones Científicas y Técnicas (CONICET), Rivadavia 1917, CP C1033AAJ, \\ Ciudad de Buenos Aires, Argentina \\ ${ }^{3}$ IADO (CONICET), Florida 8000, CP 8000, Bahía Blanca, Argentina \\ ${ }^{4}$ Department of Zoology, University of Florida, Gainesville, Florida 32611, USA \\ ${ }^{5}$ Department of Ecology and Evolutionary Biology, Brown University, Providence, Rhode Island 02912 USA
}

\begin{abstract}
Coupling experiments at small spatial scales with large-scale surveys can help to generalize experimental results across large spatial scales. The goal of the present study was to evaluate patterns of crab herbivory within and, at a larger scale, between many southwestern (SW) Atlantic salt marshes. Hence, we conducted experiments in an Argentinean salt marsh to elucidate the effects of crab Chasmagnathus granulatus grazing on the cordgrass Spartina densiflora and the factors that can affect this interaction, and then examined the potential generality of these results across SW Atlantic salt marshes from Brazil to Argentina (15 marshes, range $\approx 2000 \mathrm{~km}$ ). Experimental examination of the effects of crabs (control and exclusion) on marsh grass transplants, and factors that can affect them, i.e. the presence or absence of plant neighbors and marsh height (middle and low), revealed that crab herbivory decreased plant biomass and increased stem mortality; however, herbivory effects were significantly diminished in the presence of plant neighbors and with increasing marsh elevation. Our geographical survey showed that crab herbivory is common in SW Atlantic salt marshes, with more than $20 \%$ of leaves damaged in most marshes and with greater consumption at marshes with higher crab densities. In addition, plants at the lower edge of marshes were generally the most consumed (max. $>60 \%$ leaves consumed) and crabs preferred $S$. alterniflora over $S$. densiflora. Over a regional spatial scale, our results suggest that herbivory may affect plant production at some marshes and can also play a role in limiting the lower tidal elevation limit of low-marsh plants.
\end{abstract}

KEY WORDS: Herbivory $\cdot$ Spartina $\cdot$ Salt marshes $\cdot$ Chasmagnathus granulatus $\cdot$ SW Atlantic

Resale or republication not permitted without written consent of the publisher

\section{INTRODUCTION}

Plant growth can be controlled from the bottom-up by nutrients and/or physical factors, and from the topdown by grazers and their predators. Examples of top-down regulation (Halpern et al. 2006), bottom-up effects (Nixon \& Buckley 2002) and simultaneous control (Nielsen 2003) are numerous and can be found in aquatic (Williams et al. 2002) and terrestrial systems (Chase et al. 2000). In many cases, both top-down and bottom-up forces are important (Nielsen 2003). Many of these studies, however, have been conducted on local scales, and there is little information on how these factors vary across large spatial scales. Coupling smallscale experiments with large-scale surveys has been suggested as a way to generalize results to larger spatial scales (Wootton 2001).

Bottom-up factors have long been thought to regulate plant growth in salt marsh communities (Valiela et al. 1976). Recent work, however, has also highlighted 
the importance of grazers in marsh systems (Jefferies et al. 2006). Marsh herbivores include crabs (Bortolus \& Iribarne 1999), feral horses (Furbish \& Albano 1994), cattle (Andresen et al. 1990), hares and geese (Dormann et al. 2000), beetles (Rand 1999), plant hoppers (Daehler \& Strong 1995), snails (Silliman \& Zieman 2001) and rodents (Vicari et al. 2002). Although some of these grazers are able to strongly suppress marsh grass growth, their regulatory role was considered relatively unimportant by marsh ecologists since their occurrence in marshes is often spatially and temporally patchy (Silliman \& Zieman 2001). However, results from small-scale caging experiments at different sites in North America (Virginia: Silliman \& Zieman 2001; Georgia: Silliman \& Bertness 2002; Louisiana: Silliman et al. 2005; Hudson Bay and James Bay, Canada: Abraham et al. 2005) coupled with large-scale surveys of grazing intensity (Silliman \& Zieman 2001, Abraham et al. 2005), reveal that grazing is an important determinant of marsh grass production across large geographic areas.

Herbivory has also been suggested to be important in southwestern (SW) Atlantic marshes (Bortolus \& Iribarne 1999, Costa et al. 2003). Salt marshes between southern Brazil $\left(32^{\circ} \mathrm{S}\right)$ and northern Patagonia $\left(42^{\circ} \mathrm{S}\right)$ are dominated by Spartina densiflora, Spartina alterniflora, and Sarcocornia perennis (Isacch et al. 2006) and are also distinguished by the presence of the burrowing crab Chasmagnathus granulatus (Iribarne et al. 1997). These crabs ( 3 to $4 \mathrm{~cm}$ in carapace width) inhabit almost the entire intertidal zone (Iribarne et al. 1997) and are preyed upon mainly by the American oystercatcher Haematopus palliatus (Daleo et al. 2005) and Olrog's gull Larus atlanticus (Copello \& Favero 2001), but these predators do not seem to affect crab population size (Favero et al. 2001). Field observations and gut content analysis indicate that $C$. granulatus is a herbivore-detritivore in salt marshes (Iribarne et al. 1997, Bortolus \& Iribarne 1999) and stable isotope analyses confirm that Spartina spp. plants are their primary food source (Botto et al. 2005). As in North America (Atlantic coast of USA; Silliman \& Zieman 2001, Silliman \& Bertness 2002, Silliman et al. 2005), invertebrate grazers (i.e. crabs) in South America can exert strong control over marsh plants (Bortolus \& Iribarne 1999, Costa et al. 2003, Bortolus et al. 2004). Herbivory by $C$. granulatus can decrease aerial biomass of $S$. densiflora (primarily through consumption of young shoots) by up to $87 \%$ (Bortolus \& Iribarne 1999) and can have strong effects on $S$. alterniflora (Costa et al. 2003). Given that: (1) Spartina spp. are the primary food of C. granulatus (Botto et al. 2005), (2) C. granulatus exhibits a widespread distribution and high abundance, and (3) C. granulatus is able to suppress marsh grass growth (Bortolus \& Iribarne 1999) and, poten- tially, regulate plant distribution (Costa et al. 2003), we predict that herbivory by $C$. granulatus plays a key regulatory role in SW Atlantic marshes.

Although crab herbivory may be strong at sites over large spatial scales, the intensity of grazing within marshes has been shown to vary at small spatial scales. For example, tidal gradients are important indirectlyregulating forces, with the highest level of insect grazing occurring in the mid-marsh (Rand 2002). In addition, plant neighbors are also important (i.e. without neighbors: bare patches; with: marsh matrix), with some studies showing larger herbivore impacts when neighbors are present (Dormann et al. 2000), while others show the opposite pattern (Rand 2004). Grazers can also have stronger impacts on marsh edges at the interface between marsh vegetation and exposed mudflat zones (Silliman et al. 2005) and physical disturbance can also mediate consumer impacts, as grazers can be less effective in marsh canopies than at edges of disturbance-generated patches (Rand 1999). How Chasmagnathus granulatus herbivory varies across elevation gradients or in relation to the presence of neighbors, however, has received little attention.

In the present study, we examine small- (10s of $\mathrm{m})$ and large-scale $(100 \mathrm{~s}$ of $\mathrm{km})$ spatial variation in herbivore pressure by Chasmagnathus granulatus in SW Atlantic salt marshes by: (1) experimentally evaluating the extent to which crab herbivory controls the growth of marsh plants across the intertidal, and then (2) quantifying the intensity of crab herbivory on Spartina densiflora and S. alterniflora along $2000 \mathrm{~km}$ of SW Atlantic coastline, comprising most of the distribution range of both plant species coexisting with this crab in eastern South America.

\section{MATERIALS AND METHODS}

Transplant experiments. Experiments were carried out at the Mar Chiquita coastal lagoon $\left(37^{\circ} 46^{\prime} \mathrm{S}\right)$, a 'UNESCO Man and the Biosphere' reserve that has been intensively studied over the last 2 decades (Iribarne 2001). This is a brackish body of water (salinity values range between 0.5 and $34 \%$ ) affected by lowamplitude tides $(\leq 1 \mathrm{~m})$. The marginal prairie is characterized by halophytic vegetation, dominated by Spartina densiflora and Sarcocornia perennis (Isacch et al. 2006). The burrowing crab Chasmagnathus granulatus is distributed in the tidal flats and in the marshes and is one of the most important macroinvertebrates of SW Atlantic salt marshes (Iribarne et al. 1997).

Given that plant growth can be affected by crab herbivory and that it can vary with marsh height and the presence of plant neighbors, we conducted an experi- 
ment to evaluate the efffect of these variables on plant growth. It consisted of a $2 \times 2 \times 2$ factorial design using transplants, with 2 marsh heights (middle and low; elevation difference: $12 \mathrm{~cm}$ ), presence and absence of neighbors (marsh matrix vs. bare patches), and $2 \mathrm{crab}$ herbivory intensities (zero and cage control). Treatments consisted of replicated marsh-plant transplants $(\mathrm{n}=12)$ individually surrounded with wire mesh cages $(35 \times 35 \times 40 \mathrm{~cm}$; mesh size: $1.5 \mathrm{~cm}$; cage control treatments had 3 entrances that permitted movement of all crabs, regardless of size). All other invertebrate herbivores present in the marsh could easily pass through the mesh (A. Canepuccia pers. comm.) and field observations showed that they produce leaf wounds different than those of crabs. Even though vertebrate herbivores could potentially be excluded, when present in the marsh they forage at higher intertidal levels (A. Canapuccia unpubl. data) and produce very distinctive marks, given that they cut the stems a few centimeters above ground level (Vicari et al. 2002).

Transplants were extracted as cores $(10 \mathrm{~cm}$ diameter, $35 \mathrm{~cm}$ deep, included $90 \%$ of root biomass; P. Daleo unpubl. data) from areas without herbivory (plants were located away from where crabs were found). Preliminary experiments at the same time and location showed no differences between transplanted and non-transplanted units (both with neighbors and herbivory) and between cage control and non-caged transplants, for all variables measured. Individual units from with-neighbor treatments were located in the middle of different Spartina densiflora patches (approx. $2 \times 2 \mathrm{~m}$ ) and those assigned to no-neighbor treatments were located in naturally occurring adjacent bare areas. This experiment could not be replicated in other marshes given that periodical monitoring was necessary, which was not possible due to logistic constrains.

To evaluate the effect of experimental treatments on crab grazing intensity, we used percent of leaves grazed per stem (Rand 1999, 2002, 2004), maximum height of the transplant (Costa et al. 2003), percent of live stems (Bortolus et al. 2004) and change in the number of stems per transplant as the response variables. The percent of live leaves damaged per stem (i.e. lacking their tips; when crabs consume leaves, they remove on average more than $20 \%$ of leaf biomass; J. Alberti unpubl. data) was measured for 1 randomly chosen stem per replicate during March 2003, $70 \mathrm{~d}$ after the beginning of the experiments. The null hypothesis of no difference in percent leaves damaged in transplants with or without neighbors, with or without crabs and in the low and middle marsh was evaluated using a 3-way ANOVA, considering neighbor treatment, crab access and tidal elevation as fixed factors (log transformed; Zar 1999).
Tukey's honestly significant difference (HSD) tests were used for post hoc contrasts.

To evaluate the effect of transplant treatments on plant performance, the proportion and number of live stems and maximum height were measured for transplants in the low marsh (middle marsh transplants were lost due to wrack disturbance) after $1.5 \mathrm{yr}$ (in June 2004). The change in the number of stems (i.e. ratio between final and initial number of stems; log transformed), maximum height and the proportion of live stems, with or without neighbors, and with or without crabs, were evaluated using 2-way ANOVAs (neighbor and crab access treatments as fixed factors).

Local herbivory patterns. We also sampled our experimental marsh site for spatial and temporal patterns in crab herbivory to confirm that the results of experiments were indeed found in natural situations, and also to detect if small-scale patterns (i.e. within a marsh) remained the same when changing the scale (intra- vs. inter-marsh comparison). Hence, we evaluated how marsh height, plant location (edge or interior of marsh matrix) and crab density influenced herbivory. We used a $2 \times 2$ factorial design, with 2 marsh heights (middle and low) and 2 locations (marsh-mudflat borders and inside marsh matrix). We scored percent leaves damaged per stem on 120 stems in each category during the fall (the time of the year with the greatest herbivory; J. Alberti unpubl. data). A 2-way ANOVA (marsh level and plant location as fixed factors) was used to contrast differences in herbivory (i.e. percent leaves damaged per stem) between factors.

Since herbivore density can be related to grazing intensity (Lubchenco 1983) we evaluated this in our system. We measured burrow density (an estimator of crab density; Iribarne et al. 1997) by counting the number of burrows in random $0.25 \mathrm{~m}^{2}$ quadrats $(\mathrm{n}=72)$. In each quadrat, we randomly selected 1 stem and scored the percent leaves damaged. Regression analysis (Zar 1999) between burrow densities and herbivory was performed.

Given that grazers can have strong effects on the interface between marsh vegetation and exposed mudflats (Silliman et al. 2005), a border marking experiment was performed at 2 localities (Mar Chiquita, Spartina densiflora; and San Antonio Bay, $40^{\circ} 48^{\prime} \mathrm{S}, S$. alterniflora) to evaluate if the intensity of grazing affects stem survival. We identified 2 marshmudflat borders with different grazing intensities (probably due to areal extent in the mudflat areas) at these 2 localities (Mar Chiquita: 7.5 and 14.2\% of leaves were grazed in the selected borders; San Antonio Bay: 29.6 and $47.4 \%$ ). Then, 5 groups of 10 live stems were marked at each border and locality, and the number of dead stems per group was counted after 1 yr. Significant differences in the mean number of 


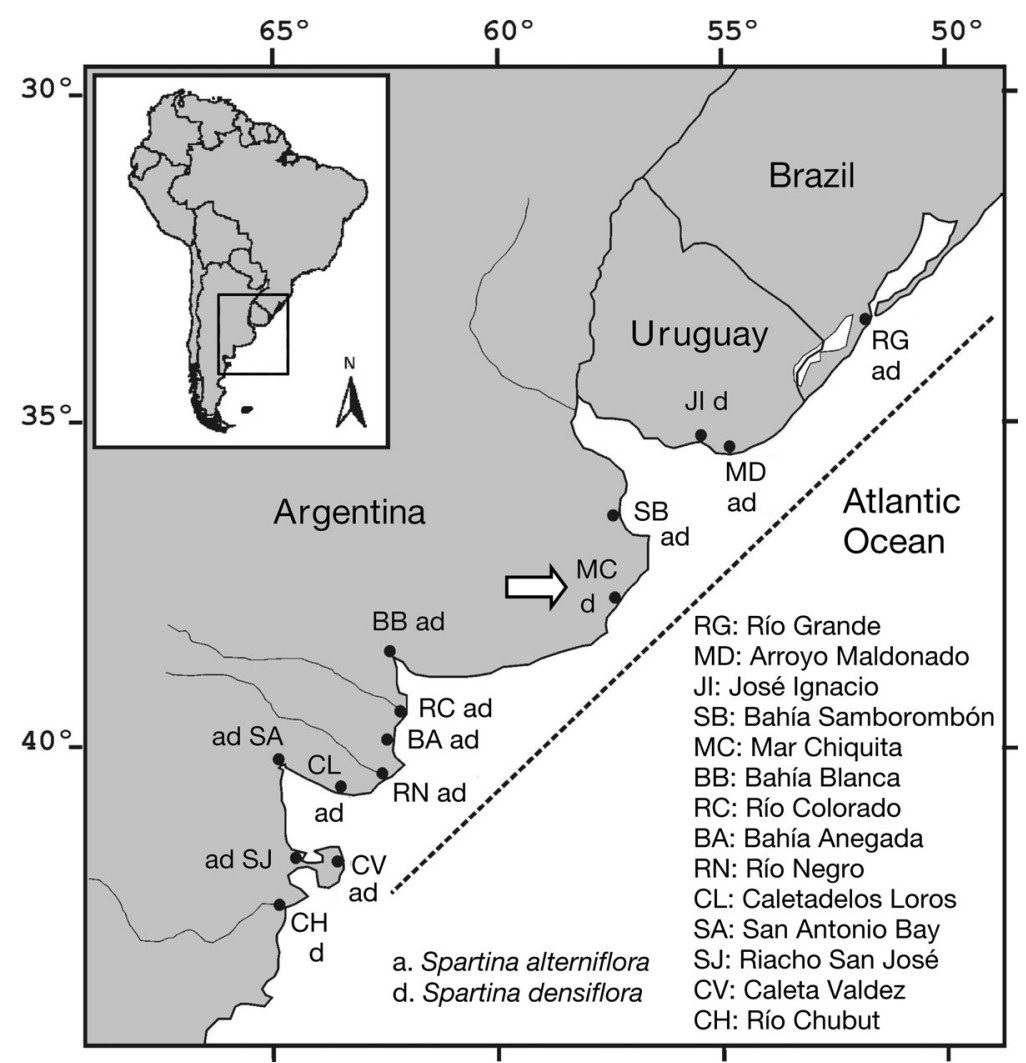

Fig. 1. Chasmagnathus granulatus. Most important (in terms of areal extent) SW Atlantic salt marshes. Dashed line indicates geographic range of C. granulatus; : marsh locations; arrow highlights our experimental site. A small population of C. granulatus is present at $\mathrm{SJ}$, but this species is not present at $\mathrm{CV}$

dead stems between edges were evaluated using a Mann-Whitney $U$-test (Conover 1980) at each marsh locality.

Large-scale surveys. Surveys were conducted in 15 marshes over a range of more than $2000 \mathrm{~km}$ north to south to (1) examine how grazing intensity varied across latitude; (2) evaluate the potential generality of survey and experiment results conducted at our main study site; and (3) detect possible changes in smallscale patterns when changing to a larger scale. Herbivory was measured in most SW Atlantic marshes inhabited by Chasmagnathus granulatus (encompassing almost the entire geographical range of C. granulatus) and dominated by Spartina alterniflora and $S$. densiflora (Fig. 1). Data were collected in 3 marshes of Río Grande do Sul (Río Grande) in Brazil (32 ${ }^{\circ} 1^{\prime} \mathrm{S}$; $\left.32^{\circ} 6^{\prime} \mathrm{S} ; 32^{\circ} 9^{\prime} \mathrm{S}\right)$; and all others in Argentina: Bahía Samborombón (36¹2'S), Mar Chiquita coastal lagoon, Bahía Blanca (3853'S), 3 marshes in Bahía Anegada $\left(40^{\circ} 33^{\prime} \mathrm{S}\right)$, Río Negro estuary $\left(41^{\circ} 00^{\prime} \mathrm{S}\right)$, San Antonio Bay, Caleta de los Loros $\left(41^{\circ} 01^{\prime} \mathrm{S}\right), 2$ marshes in Riacho San José $\left(42^{\circ} 25^{\prime} \mathrm{S}\right)$ and the Río Chubut estuary $\left(43^{\circ} 20^{\prime} \mathrm{S}\right)$. S. alterniflora was present in Río Grande, Bahía Samborombón, Bahía Blanca, Bahía Anegada, Río Negro estuary, Caleta de los Loros, San Antonio Bay and Riacho San José, while $S$. densiflora was found in every locality. $S$. alterniflora and $S$. densiflora co-occurred at Río Grande, Bahía Samborombón, Bahía Blanca, Río Negro estuary and San Antonio Bay.

To examine the generality of the results at our experimental site, we evaluated the effect of plant location (edges vs. interiors of marshes) and marsh height (middle vs. low) on crab herbivory in the marshes described above. We also looked for largescale patterns of herbivory in relation to crab density and the plant species present.

To investigate the effect of herbivores in relation to plant location (marsh stand vs. marsh edge), percent leaves damaged per stem was calculated for all marshes $(n=30$ per category). Differences in percent leaves damaged between the edge and marsh interior were compared using a $t$ test for unequal variances (Welch approximation $t_{c i}$ Zar 1999) for each marsh (herbivory data on marsh matrix were not collected in Río Grande 2, and, thus, not analyzed). The $t_{c}$ is equal to the $t$-value when sample sizes are the same, but degrees of freedom decrease as the difference between variances of the 2 groups increases (Zar 1999). When the assumptions of parametric statistics were not met and no transformations were possible, Mann-Whitney $U$-tests were used.

To determine if herbivory was similar across tidal heights, herbivory data (percent leaves damaged per stem) were collected at 2 different marsh heights (middle and low marsh) at Bahía Blanca, Bahía Anegada and San Antonio Bay. Differences in percent leaves damaged per stem between marsh heights were compared using a $t_{c}$-test for Bahía Anegada and San Antonio Bay and a Mann-Whitney U-test for Bahía Blanca. Only stems from the marsh edge were considered for the analysis, since we could not collect data on all middle-marsh interiors. Given that there is no information available about most of the marshes considered, marsh heights sampled do not necessarily reflect inundation frequency, but only a relative height compared to other vegetated zones of the marsh.

We also looked at the relationship between crab density and herbivory at a larger spatial scale, to detect possible changes in patterns with changes in scale. To evaluate the association between the intensity of grazing on marsh edges and local crab abundance, mean 
densities of burrows (average number of burrows in 10 random $0.25 \mathrm{~m}^{2}$ quadrats) and mean values of herbivory on marsh edges (percent leaves damaged) were calculated for each sampled marsh, and then a regression analysis was performed (Zar 1999). Bahía Samborombón and 2 Bahía Anegada marshes were not included because burrow densities were not collected.

Spartina alterniflora has been found to be preferred by Chasmagnathus granulatus over $S$. densiflora in southern Brazil (Costa et al. 2003). To determine if this was common across SW Atlantic salt marshes, percent leaves damaged was calculated for 60 randomly chosen stems of each species in marshes where both Spartina species were present. Then, different $t_{c}$-tests (for Bahía Samborombón, Río Negro and San Antonio) or Mann-Whitney $U$ tests (Río Grande 1 and Bahía Blanca) were used to evaluate the null hypotheses of no difference in herbivory between the 2 species for each marsh with both Spartina species present. Since plant survival can be positively related to population density (Bruno et al. 2003) we compared stem densities of both plant species as a possible explanation of differences in grazing intensities between the two. Differences in mean stem densities (the average number of live stems on five $20 \times 20 \mathrm{~cm}$ random quadrats) between both Spartina species were evaluated using a $t_{c}$-test (one value per species per marsh, for all marshes except Río Grande 1 and Bahía Samborombón, where these data could not be collected).

\section{RESULTS}

\section{Transplant experiment}

Crab herbivory in the low marsh at Mar Chiquita was twice as high as in the middle marsh, and more than 3 times higher when transplants were deployed in bare patches (no plant neighbors) with crabs present (Tables 1 \& 2). In the low marsh, the same pattern was observed when analyzing plant performance (i.e. transplant size, height and proportion alive) after 1.5 yr. Growing in bare patches and without herbivory led to an almost $100 \%$ increase in stems (Tables $3 \& 4$ ). Herbivory reduced the proportion of live stems by $50 \%$ in bare patches and the maximum height of transplants by $45 \%$ (Tables $3 \& 4$ ).
Table 1. Results of herbivory on the transplant experiment. Mean percent leaves damaged per stem (SE) as a function of the different treatments (i.e. marsh height, neighbor presence [bare mud, no neighbors vs. marsh stand, with neighbors], and herbivore access)

\begin{tabular}{|lcccc|}
\hline \multirow{2}{*}{ Transplants } & \multicolumn{2}{c}{ Middle marsh } & \multicolumn{2}{c}{ Low marsh } \\
& Control & Crab exclusion & Control & Crab exclusion \\
\hline In bare mud & $27.08(8.77)^{\mathrm{a}}$ & $2.08(2.08)$ & $56.25(8.40)^{\mathrm{a}}$ & $19.44(7.06)$ \\
In marsh stands & $11.81(5.28)$ & $7.64(4.03)$ & $17.36(8.11)$ & $13.19(8.55)$ \\
a Treatment is significantly different $(\mathrm{p}<0.05)$ & from the others for a given \\
marsh height & & & \\
\hline
\end{tabular}
nt. Results of the 3-way ANOVA: percent leaves damaged per stem

\begin{tabular}{|lrrrr|}
\hline Effect & df & MS & \multicolumn{1}{c|}{$F$} & $\mathrm{p}$ \\
\hline Marsh height & 1 & 4983.36 & 8.64 & $<0.01$ \\
Neighbors & 1 & 4514.61 & 7.83 & $<0.01$ \\
Herbivory & 1 & 7379.20 & 12.79 & $<0.001$ \\
Marsh height $\times$ Neighbors & 1 & 1881.51 & 3.26 & 0.07 \\
Marsh height $\times$ Herbivory & 1 & 209.06 & 0.36 & 0.55 \\
Neighbors $\times$ Herbivory & 1 & 4288.92 & 7.43 & $<0.01$ \\
Marsh height $\times$ Neighbors $\times$ Herbivory & 1 & 209.06 & 0.36 & 0.55 \\
Error & 88 & 576.93 & & \\
& & & &
\end{tabular}

\section{Local herbivory patterns}

Edge plants from the low marsh of Mar Chiquita were more consumed; growing inside the marsh matrix or in the middle marsh reduced crab herbivory (percent leaves damaged) by $50 \%$ (interaction effect: $\left.F_{1,476}=10.97, \mathrm{p}<0.001\right)$. No association was found between crab density and herbivory at Mar Chiquita $\left(r^{2}=0.01, n=72, p>0.39\right)$. Stems on marsh edges with high herbivore damage at San Antonio Bay (Spartina alterniflora), had mortality 2.2 times higher than on

Table 3. Results of plant performance on transplant experiments in the low marsh

\begin{tabular}{|lcc|}
\hline Transplants & Control & Crab exclusion \\
\hline $\begin{array}{l}\text { Change in stem number } \\
\text { In bare mud }\end{array}$ & $1.29(0.28)$ & $2.05(0.25)^{\mathrm{a}}$ \\
In marsh stands & $0.97(0.12)$ & $0.90(0.07)$ \\
Proportion of live stems & & \\
In bare mud & $30.60(7.99)^{\mathrm{a}}$ & $58.83(4.74)$ \\
In marsh stands & $43.78(7.09)$ & $44.73(5.82)$ \\
Maximum height & & \\
$\begin{array}{l}\text { In bare mud } \\
\text { In marsh stands }\end{array}$ & $25.75(6.89)^{\mathrm{a}}$ & $46.50(4.43)$ \\
a Treatment is significantly different $(\mathrm{p}<0.05)$ from the \\
others for a given dependent variable
\end{tabular}


Table 4. Transplant experiment in the low marsh. Results of the 2-way ANOVA

\begin{tabular}{|lrrrr|}
\hline & df & MS & \multicolumn{1}{c|}{$F$} & $\mathrm{p}$ \\
\hline Change in stem number & & & & \\
Neighbors & 1 & 0.54 & 12.28 & $<0.01$ \\
Herbivore access & 1 & 0.20 & 4.51 & $<0.05$ \\
Neighbors $\times$ Herbivore access & 1 & 0.21 & 4.83 & $<0.05$ \\
Error & 44 & 0.04 & & \\
Proportion of live stems & & & & \\
Neighbors & 1 & 2.54 & 0.01 & 0.94 \\
Herbivore access & 1 & 2552.76 & 4.99 & $<0.05$ \\
Neighbors $\times$ Herbivore access & 1 & 2232.13 & 4.37 & $<0.05$ \\
Error & 44 & 511.13 & & \\
Maximum height & & & & \\
Neighbors & 1 & 494.08 & 1.42 & 0.24 \\
Herbivore access & 1 & 954.08 & 2.75 & 0.10 \\
Neighbors $\times$ Herbivore access & 1 & 1680.33 & 4.84 & $<0.05$ \\
Error & 44 & 347.14 & & \\
\hline
\end{tabular}

edges with less damage $(U=1, \mathrm{n}=10, \mathrm{p}<0.05)$, but there were no significant differences at Mar Chiquita $(U=6, \mathrm{n}=10, \mathrm{p}>0.17)$. grazing intensities at least twice those of $S$. densiflora (Río Grande 1: $U=1144, \mathrm{n}=120, \mathrm{p}<0.001$; Bahía Samborombón: $t=6.81$, df $=118, \mathrm{p}<0.001$; Bahía Blanca: $U$ $=1421.5, \mathrm{n}=120, \mathrm{p}<0.05$; Río Negro: $t=2.89, \mathrm{df}=110$, $\mathrm{p}<0.01$; San Antonio Bay: $t=4.90, \mathrm{df}=89, \mathrm{p}<0.001$ ).

\section{DISCUSSION}

Results of our small-scale grazing experiments, combined with large-scale surveys of salt marshes throughout Argentina and Brazil inhabited by Chasmagnathus granulatus, suggest that crab herbivory may (1) play an important role in regulating the production (through increased plant mortality) of Spartina spp.; and (2) potentially affect its lower intertidal distribution in some marshes. In half of the marshes surveyed that were inhabited by C. granulatus, crab herbivory was higher than at our experimental site, where it significantly affected plant performance and stem survival. Crab herbivory is a widespread phenomenon and is most intense (1) on the edges of bare patches; (2) in marshes with higher densities of crabs; (3) in the low marsh; and (4) on leaves of $S$. alterniflora in comparison to $S$. densiflora.

\section{Crab herbivory patterns in marshes}

Most SW Atlantic marshes inhabited by the burrowing crab Chasmagnathus granulatus showed more than $20 \%$ of leaves damaged per stem, and similar or more intense herbivore pressure on marsh edges than interiors (Table 5). As at Mar Chiquita, the lower marsh edges of Bahía Blanca (Spartina alterniflora), Bahía Anegada (S. densiflora) and San Antonio Bay ( $S$. alterniflora) showed almost 3 times more damaged leaves than their middle-marsh edges $(U=294.5, \mathrm{n}=60, \mathrm{p}<$ 0.05; $t=5.11$, df $=53, \mathrm{p}<0.001 ; t=$ 4.73, df $=48, \mathrm{p}<0.001$, respectively). Even though no association was found between crab density and herbivory at Mar Chiquita, when examining this relationship at a larger scale, using marshes as sampling units instead of quadrats, marshes with higher mean crab densities had more damaged leaves on their edges (Fig. 2). S. densiflora stem densities were more than 4 times larger than those of $S$. alterniflora ( $t=3.58$, df $=6, \mathrm{p}<0.01)$. In all marshes with both Spartina species present, $S$. alterniflora experienced
Table 5. SW Atlantic marshes visited in this study (north to south), Spartina species considered, percentage of leaves damaged (SE) at the edge and interior of marshes, and p-values from edge vs. interior comparison. Different numbers next to locality names denote different isolated marshes within the same locality. The total number of stems analyzed per plant location within the marsh was 30 for all localities except at Mar Chiquita $(\mathrm{n}=120)$. Note that Chasmagnathus granulatus was not found at Riacho San José 1 or Río Chubut, and that in Río Grande 3 only juveniles were found, and they do not eat live plants (Botto et al. 2005). ' $U$ ' next to p-values denote comparisons using Mann-Whitney $U$-test; otherwise $t_{c}$-tests were used. nd = no data collected

\begin{tabular}{|c|c|c|c|c|}
\hline \multirow[t]{2}{*}{ Locality } & \multirow[t]{2}{*}{ Species } & \multicolumn{2}{|c|}{ Leaves damaged (\%) } & \multirow[t]{2}{*}{$\mathrm{p}$} \\
\hline & & Edge & Marsh matrix & \\
\hline Río Grande 1 & S. alterniflora & $24.1(3.5)$ & $8(2.5)$ & $<0.001 U$ \\
\hline 1 & S. densiflora & $7.2(2.6)$ & $1.1(1.1)$ & $<0.05 U$ \\
\hline 2 & S. alterniflora & $25.2(5.4)$ & nd & \\
\hline 3 & S. alterniflora & $0(0)$ & $1.9(1.4)$ & $>0.15 U$ \\
\hline \multirow[t]{2}{*}{ Samborombón } & S. alterniflora & $75(3.1)$ & $51.7(3.9)$ & $<0.001$ \\
\hline & S. densiflora & $41.2(4.2)$ & $29.4(3.9)$ & $<0.05$ \\
\hline Mar Chiquita & S. densiflora & $37(2)$ & $17.7(1.6)$ & $<0.001$ \\
\hline \multirow[t]{2}{*}{ Bahía Blanca } & S. alterniflora & $24.8(4.8)$ & $7.9(2.6)$ & $<0.01 U$ \\
\hline & S. densiflora & $13.9(4.6)$ & $4.7(2.3)$ & $>0.1 \mathrm{U}$ \\
\hline Bahía Anegada 1 & S. alterniflora & $20.6(4.8)$ & $49.3(5.7)$ & $<0.001$ \\
\hline 2 & S. alterniflora & $62.3(6)$ & $28.2(5.3)$ & $<0.001$ \\
\hline 3 & S. densiflora & $46.4(5.3)$ & $16.8(3.9)$ & $<0.001 U$ \\
\hline \multirow[t]{2}{*}{ Río Negro } & S. alterniflora & $64.9(5.3)$ & $13.7(4)$ & $<0.001$ \\
\hline & S. densiflora & $24.2(4.8)$ & $21.1(5.5)$ & $>0.6$ \\
\hline \multirow[t]{2}{*}{ San Antonio } & S. alterniflora & $47.4(6.2)$ & $29(6.1)$ & $<0.05$ \\
\hline & S. densiflora & $20.4(3.8)$ & $6.3(2.2)$ & $<0.01$ \\
\hline Caleta de los Loros & S. alterniflora & $3.6(2.1)$ & $15.5(4.2)$ & $<0.05$ \\
\hline Riacho San José 1 & S. alterniflora & $0(0)$ & $0.7(0.7)$ & $>0.31 U$ \\
\hline 2 & S. densiflora & $19.4(5.5)$ & $21.1(4.4)$ & $>0.5$ \\
\hline Río Chubut & S. densiflora & $1.7(1.2)$ & $0(0)$ & $>0.15 U$ \\
\hline
\end{tabular}




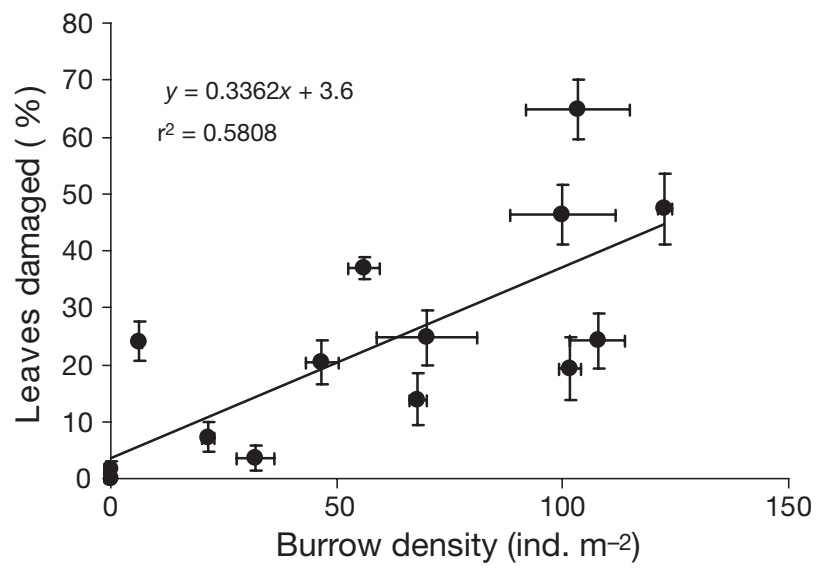

Fig. 2. Regression between mean density of burrows in Mar Chiquita marsh and mean percentage of leaves damaged per stem. Vertical and horizontal lines denote SE of the mean values $(\mathrm{n}=30$ for the percentage of leaves damaged per stem, $\mathrm{n}=10$ for burrow density)

\section{Local variation in herbivore pressure}

In the Mar Chiquita salt marsh, herbivory in transplant experiments was greater on plants in bare patches than in the marsh matrix. Our data suggest that this grazing pattern was generated by a predation dilution effect (i.e. the probability of a particular prey being consumed decreases as the number or density of potential prey increases), rather than by apparent competition (Holt 1984), as previously found in New England marshes (Rand 1999), or increased susceptibility to herbivory due to the lack of facilitation provided by neighbors (plant neighbors that reduced the incidence of harsh physical factors via shade indirectly permitted plants to become less susceptible to herbivory due to a reduction in the stress these plants experienced; Rand 2004). Apparent competition was not a possible explanation for the increased grazing intensity in bare patches because no other plant species were present. Plants in bare patches with herbivores excluded exhibited greater growth and a similar proportion of live stems than those in the dense marsh matrix, strongly indicating that physical factors did not stress plants transplanted into bare patches, and suggesting that intraspecific competition for nutrients is more important than herbivory in the marsh matrix. Hence, another potential explanation arises: differences in grazing intensity between transplants in bare patches (or plants in the marsh edge) and in the marsh matrix can potentially indicate crab feeding preferences on plants with higher nitrogen content (only if differences in competition translate into differences in nutrient contents on plant tissues). Further experiments are needed to confirm this speculation.
Plant survival can be positively related to population density (Bruno et al. 2003) and, by definition, stems on edges have fewer neighbors than stems on the marsh matrix. Given this pattern, increased grazing intensity on the edges of bare areas (or on transplants into them) may have been due to a predation dilution effect in the marsh interior and/or increased mechanical constraint on the movement of crabs. In fact, previous work in Brazil found a negative association between Spartina alterniflora stem densities and Chasmagnathus granulatus grazing intensity (Costa et al. 2003).

We also found that herbivore pressure varied with tidal height, with herbivory greatest in the low marsh, similar to previous findings (Rand 2002, Silliman \& Bertness 2002). In previous studies, differences in herbivory across tidal gradients reflected differences in predation pressures on herbivores (Silliman \& Bertness 2002) or changes in host plant composition (Rand 2002). However, herbivores may also respond to underlying environmental conditions that affect them directly, such as in some mangrove systems, where crab seed predators prefer feeding at lower tidal elevations where desiccation stress is reduced (Sousa \& Mitchell 1999). The reason why Chasmagnathus granulatus eats more plants at lower intertidal levels remains unknown.

\section{Generality of patterns over a geographic range}

A common pattern found in almost all marshes was that plants on the edges of patches were more heavily grazed than plants located in the marsh interior. The opposite pattern was found in only 2 of the sampled marshes (Bahía Anegada 1 and Caleta de los Loros), and in these marshes crabs lived only in the marsh interior, suggesting that proximity to food may swamp benefits of feeding along more accessible edge areas, or that when crabs also live on bare surface, they accumulate and feed on the nearest plants (edges). The tendency for crabs to concentrate their herbivory on edges of bare patches could have important community consequences: herbivory concentrated on edges of plant distribution can prevent plant colonization and patch closure (Bishop 2002), suppressing potential primary production (Silliman et al. 2005) and ecosystem function associated with areas of high plant cover (Fagan \& Bishop 2000). However, to confirm this hypothesis, exclusion experiments on the edges of plant distributions are needed.

Crabs showed a marked preference for feeding on Spartina alterniflora over $S$. densiflora, a pattern observed previously in a study examining plant competition and zonation in Brazil (Costa et al. 2003). As discussed before, these grazing preference patterns could 
be attributed to accessibility issues, due to the natural differences in stem densities; $S$. densiflora tillers are more dense and difficult to maneuver through than those of $S$. alterniflora. Alternatively, these differences could represent true crab preferences for $S$. alterniflora tissue and leaves based on any number of possible traits (e.g. nutrient content, silica content, toughness, phenols, other chemical and/or structural defenses). Another alternative explanation for the observed S. alterniflora preference could be the distribution range of both species within a particular marsh, given that crabs graze more intensely in the low marsh (Tables 1 $\& 2$ ) and that $S$. alterniflora occupies the lower reaches of the marsh when both species coexist (Isacch et al. 2006). Crab herbivory is more intense in these lower areas and it can increase $S$. alterniflora mortality (see 'Results'), which may, hypothetically, affect mudflat colonization rate by plants in the lower reaches of the intertidal. At other marshes dominated by $S$. densiflora, the lower distribution limits of this plant are generally thought to be controlled by inundation frequency, as differences of $5 \mathrm{~cm}$ in intertidal height have strong effects on $S$. densiflora survival (Castillo et al. 2000). Our results suggest that crab herbivory may potentially be an important factor controlling the lower distribution of $S$. densiflora as well.

\section{Large-scale patterns in crab herbivory}

Previous studies examining grazing intensity across latitudinal gradients found that low-latitude plants were more frequently consumed than high-latitude plants (Pennings \& Silliman 2005). In our survey of nearly $2000 \mathrm{~km}$ of coastline covering almost the entire distribution range of the crab, we found strong latitudinal differences. However, the variation of grazing intensity with latitude was not in a gradient, and it seems to be mainly affected by herbivore densities, probably because all surveys were performed in the same biogeographic region.

Plant species presence seems to be another factor affecting herbivory, given that crabs consume Spartina alterniflora more than $S$. densiflora (Costa et al. 2003). A recent study has shown that marshes dominated by $S$. densiflora are associated with higher freshwater inputs (e.g. rivers or coastal lagoons), while $S$. alterniflora dominate marshes with greater marine influences (Isacch et al. 2006). One interesting consequence of this association is that by affecting plant species dominance over large spatial scales, the presence of rivers and coastal lagoons could be driving where strong herbivore impacts will be found and thus be much more important than latitude in driving large-scale variation in herbivore pressure.

\section{Local vs. large-scale considerations: importance of scaling up}

Because crab grazing can be intense and grazing pressure should increase with crab density, we predicted that there would be a positive relationship between crab burrow density and grazing intensity. However, we only found a significant relationship between these variables at large spatial scales, when all marshes were considered together in one analysis. This scale-dependent result is likely due to the interaction between the limited scope of our survey at each site and the highly mobile nature of Chasmagnathus granulatus. Burrows can be more abundant in some places, but crabs can easily travel significant distances to feed (A. Méndez Casariego unpubl. data). Thus, while burrows tend to be more evenly distributed in a marsh, mobile and feeding crabs tend to be more concentrated, a pattern that likely hinders any attempt to correlate burrow density and herbivory at small scales. If we had limited our survey to 1 site, we would have failed to uncover the positive density-dependent relationship. This result points to the importance of incorporating large-scale surveys when assessing the relative influence of consumers, many of which are highly mobile and patchy on a small scale.

Given that crab grazing can reach higher and/or lower levels than those observed at Mar Chiquita (our experimental site; see Table 5), the effects of crab grazing are thus likely to be even more important at some marshes and less important at others than suggested by our transplant experiments conducted at one site. This pattern was also observed in similar studies conducted in North American salt marshes (see comparison of results in Silliman \& Zieman 2001 vs. Silliman \& Bertness 2002). Limiting our surveys to one or a few marshes would have led us to under- or overestimate the overall effect of crab herbivory on marsh plants. Our results highlight the importance of coupling smallscale experiments and large-scale surveys when assessing the relative importance of consumers and nutrients in marine systems.

Acknowledgements. We thank D. Alberti, M. Valiñas, A. García Coni, M. Merlo, F. Vera, C. M. Crain and J. P. Isacch for help in the field, and to L. Levin and 4 external reviewers for their valuable suggestions and corrections on previous versions of this manuscript. We also thank C. S. B. Costa for his collaborations in Río Grande and for his useful ideas and new insights. This project was supported by Universidad Nacional de Mar del Plata, Fundación Antorchas (Grant \#13900-13), ANPCyT (1-7213) and CONICET (PIP 2851; 165-01, all granted to O.I.) and a grant from the Andrew Mellon Foundation (to M.B.). J.A., M.E. and P.D. were supported by doctoral scholarships from CONICET. 


\section{LITERATURE CITED}

Abraham KF, Jefferies RL, Alisauskas RT (2005) The dynamics of landscape change and snow geese in mid-continent North America. Global Change Biol 11:841-855

Andresen H, Bakker JP, Brongers M, Heydemann B, Irmler U (1990) Long-term changes of salt marsh communities by cattle grazing. Vegetatio 2:137-148

Bishop JG (2002) Early primary succession on Mount St. Helens: impact of insect herbivores on colonizing lupines. Ecology 83:191-202

Bortolus A, Iribarne O (1999) Effects of the SW Atlantic burrowing crab Chasmagnathus granulata on a Spartina salt marsh. Mar Ecol Prog Ser 178:79-88

Bortolus A, Laterra P, Iribarne O (2004) Crab-mediated phenotypic changes in Spartina densiflora Brong. Estuar Coast Shelf Sci 59:97-107

Botto F, Valiela I, Iribarne O, Martinetto P, Alberti J (2005) Impact of burrowing crabs on $\mathrm{C}$ and $\mathrm{N}$ sources, control, and transformations in sediments and food webs of SW Atlantic estuaries. Mar Ecol Prog Ser 293:155-164

Bruno JF, Stachowicz JJ, Bertness MD (2003) Inclusion of facilitation into ecological theory. Trends Ecol Evol 18: 119-125

Castillo JM, Fernández-Baco L, Castellanos EM, Luque CJ, Figueroa ME, Davy AJ (2000) Lower limits of Spartina densiflora and $S$. maritima in a Mediterranean salt marsh determined by different ecophysiological tolerances. J Ecol 88:801-812

Chase JM, Leibold MA, Downing AL, Shurin JB (2000) The effects of productivity, herbivory, and plant species turnover in grassland food webs. Ecology 81:2485-2497

Conover WJ (1980) Practical nonparametric statistics, 2nd edn. Wiley, New York

Copello S, Favero M (2001) Foraging ecology of Olrog's gull Larus atlanticus in Mar Chiquita Lagoon (Buenos Aires, Argentina): are there age-related differences? Bird Conserv Int 11:175-188

Costa CSB, Marangoni JC, Azevedo AMG (2003) Plant zonation in irregularly flooded salt marshes: relative importance of stress tolerance and biological interactions. J Ecol 91:951-965

Daehler CC, Strong DR (1995) Impact of high herbivore densities on introduced smooth cordgrass, Spartina alterniflora, invading San Francisco Bay, California. Estuaries 18: 409-417

Daleo P, Escapa M, Isacch JP, Ribeiro P, Iribarne O (2005) Trophic facilitation by the oystercatcher Haematopus palliatus Temminick on the scavenger snail Buccinanops globulosum Kiener in a Patagonian bay. J Exp Mar Biol Ecol 325:27-34

Dormann CF, Van der Wal R, Bakker JP (2000) Competition and herbivory during salt marsh succession: the importance of forb growth strategy. J Ecol 88:571-583

Fagan WF, Bishop JG (2000) Trophic interactions during primary succession: herbivores slow a plant reinvasion at Mount St. Helens. Am Nat 155:238-251

Favero M, Bachmann S, Copello S, Mariano-Jelicich R, Silva MP, Ghys M, Khatchikian C, Mauco L (2001) Aves marinas del sudeste bonaerense. In: Iribarne O (ed) Reserva de biosfera Mar Chiquita: características físicas, biológicas y ecológicas. Editorial Martín, Mar del Plata, p 251267

Furbish CE, Albano M (1994) Selective herbivory and plant community structure in a mid-Atlantic salt marsh. Ecology 75:1015-1022

Halpern BS, Cottenie K, Broitman BR (2006) Strong top-down control in Southern California kelp forest ecosystems Science 312:1230-1232

Holt RD (1984) Spatial heterogeneity, indirect interactions, and the coexistence of prey species. Am Nat 124:377-406

Iribarne O (2001) Reserva de biosfera Mar Chiquita: características físicas, biológicas y ecológicas. Editorial Martín, Mar del Plata

Iribarne O, Bortolus A, Botto F (1997) Between-habitat differences in burrow characteristics and trophic modes in the southwestern Atlantic burrowing crab Chasmagnathus granulata. Mar Ecol Prog Ser 155:137-145

Isacch JP, Costa CSB, Rodríguez-Gallego L, Conde D, Escapa M, Gagliardini DA, Iribarne OO (2006) Distribution of saltmarsh plant communities associated with environmental factors along a latitudinal gradient on the southwest Atlantic coast. J Biogeogr 33:888-900

Jefferies RL, Jano AP, Abraham KF (2006) A biotic agent promotes large-scale catastrophic change in the coastal marshes of Hudson Bay. J Ecol 94:234-242

Lubchenco J (1983) Littorina and Fucus: effects of herbivores, substratum heterogeneity, and plant escapes during succession. Ecology 64:1116-1123

Nielsen KJ (2003) Nutrient loading and consumers: agents of change in open-coast macrophyte assemblages. Proc Natl Acad Sci USA 100:7660-7665

Nixon SW, Buckley BA (2002) 'A strikingly rich zone' — nutrient enrichment and secondary production in coastal marine ecosystems. Estuaries 25:782-796

Pennings SC, Silliman BR (2005) Linking biogeography and community ecology: latitudinal variation in plant-herbivore strength. Ecology 86:2310-2319

Rand TA (1999) Effects of environmental context on the susceptibility of Atriplex patula to attack by herbivorous beetles. Oecologia 121:39-46

Rand TA (2002) Variation in insect herbivory across a salt marsh tidal gradient influences plant survival and distribution. Oecologia 132:549-558

Rand TA (2004) Competition, facilitation, and compensation for insect herbivory in an annual salt marsh forb. Ecology 85:2046-2052

Silliman BR, Bertness MD (2002) A trophic cascade regulates salt marsh primary production. Proc Natl Acad Sci USA 99:10500-10505

Silliman BR, Zieman JC (2001) Top-down control of Spartina alterniflora production by periwinkle grazing in a Virginia salt marsh. Ecology 82:2830-2845

Silliman BR, van de Koppel J, Bertness MD, Stanton L, Mendelsohn I (2005) Drought, snails, and large-scale dieoff of southern US salt marshes. Science 310:1803-1806

Sousa WP, Mitchell BJ (1999) The effect of seed predators on plant distributions: is there a general pattern in mangroves? Oikos 86:55-66

Valiela I, Teal JM, Persson NY (1976) Production and dynamics of experimentally enriched salt marsh vegetation: belowground biomass. Limnol Oceanogr 21:245-252

Vicari RL, Fischer S, Madanes N, Bonaventura SM, Pancotto V (2002) Tiller population dynamics and production on Spartina densiflora (Brong) on the floodplain of the Paraná river, Argentina. Wetlands 22:347-354

Williams AE, Moss B, Eaton J (2002) Fish induced macrophyte loss in shallow lakes: top-down and bottom-up processes in mesocosm experiments. Freshw Biol 47:2216-2232

Wootton JT (2001) Local interactions predict large-scale pattern in empirically derived cellular automata. Nature 413: 841-844

Zar JH (1999) Biostatistical analysis, 4th edn. Prentice Hall, Upper Saddle River, NJ

Submitted: February 16, 2006; Accepted: May 30, 2007

Proofs received from author(s): October 12, 2007 